\title{
Duplication of chromosome 15 in the region 15q11-13 in a patient with developmental delay and ataxia with similarities to Angelman syndrome
}

\author{
J Clayton-Smith, T Webb, X J Cheng, M E Pembrey, S Malcolm
}

\begin{abstract}
Duplications of the proximal long arm of chromosome 15 have been seen in the Prader-Willi syndrome (PWS), and in subjects without the Prader-Willi phenotype but with other clinical features including short stature, diabetes, anal and jejunal atresia, and acanthosis nigricans. The non-PWS subjects all had different phenotypes despite the identical findings on cytogenetic analysis. A normal phenotype has also been observed in patients with similar duplications. We report a further patient with a duplication of 15q11-13 which was detected cytogenetically and confirmed on molecular genetic analysis. She has developmental delay, particularly concerning the acquisition of speech, and an ataxic gait. These are interesting clinical features in view of the association of Angelman syndrome with abnormalities of 15q11-13.

( $\mathcal{H}$ Med Genet 1993;30:529-31)
\end{abstract}

Deletions, duplications, and other chromosomal rearrangements of chromosome 15q11.2 have been reported frequently in the Prader-

Department of Medical Genetics, St Mary's Hospital, Hathersage Road, Whitfield Park, Manchester Mi3 0JH, UK.

J Clayton-Smith

Department of Clinical Genetics, Birmingham Maternity Hospital, Edgbaston, Birmingham B15 2TG UK.

$T$ Webb

Division of

Biochemistry and

Genetics, Institute of

Child Health, 30

Guilford Street,

London WC1N 1EH,

UK.

$\mathrm{X}$ J Cheng

M E Pembrey

S Malcolm

Correspondence to Dr Malcolm.

Received 18 September 1992. Revised version accepted 27 November 1992.
Willi syndrome. ${ }^{12}$ Cytogenetic deletions, inversions, and translocations involving this area of proximal 15q have also been reported in subjects with Angelman syndrome (AS)..$^{3-6}$ To date, Angelman syndrome has not been found in association with a duplication of 15q11-13. Cytogenetic examination of this region may be difficult as there is considerable normal variation in appearances, particularly of the pale band 15q11.2.5 A long 15q11.2 band may therefore occasionally be interpreted as abnormal if this is not taken into account. Comparison of the appearance with the chromosomes 15 of the parents may safeguard against this error. We report a patient who has a de novo duplication of the 15q11-13 region, initially detected on cytogenetic examination and confirmed by DNA analysis, and shown to involve the locus D15S10 which is associated with the critical region in AS. It is of interest that she has significant developmental delay, particularly in the area of language, and was noted from 2 years of age to have a wide based, ataxic gait. These clinical features are seen to a more severe degree in Angelman syndrome. ${ }^{7}$

\section{Case report}

The proband is the first born child of unrelated, healthy parents and weighed $3630 \mathrm{~g}$ at term. She has a normal younger sister. The pregnancy and neonatal period were uneventful and she smiled at 12 weeks of age, sat unsupported at 9 months, and walked independently when she was 19 months old.

At 2 years of age she came to medical attention because of delay in language development with poor vocalisation and no recognisable words. On examination she was a tall, muscular girl with an ataxic 'bobbing' gait and a tendency to fall frequently. She was lax jointed and had difficulty with gross motor coordination. When reviewed at the age of 4 years (fig 1) she continued to have a wide based, ataxic gait. Her height and weight were on the 87 th centile and her OFC on the 50th centile. She had two small café au lait patches on her skin but did not appear dysmorphic. She was now able to say some single words. An EEG and CT scan were both normal. She had ginger hair and blue eyes but was not significantly hypopigmented compared to the other family members. At 6 years of age she is globally developmentally delayed, functioning at a 3 year level.

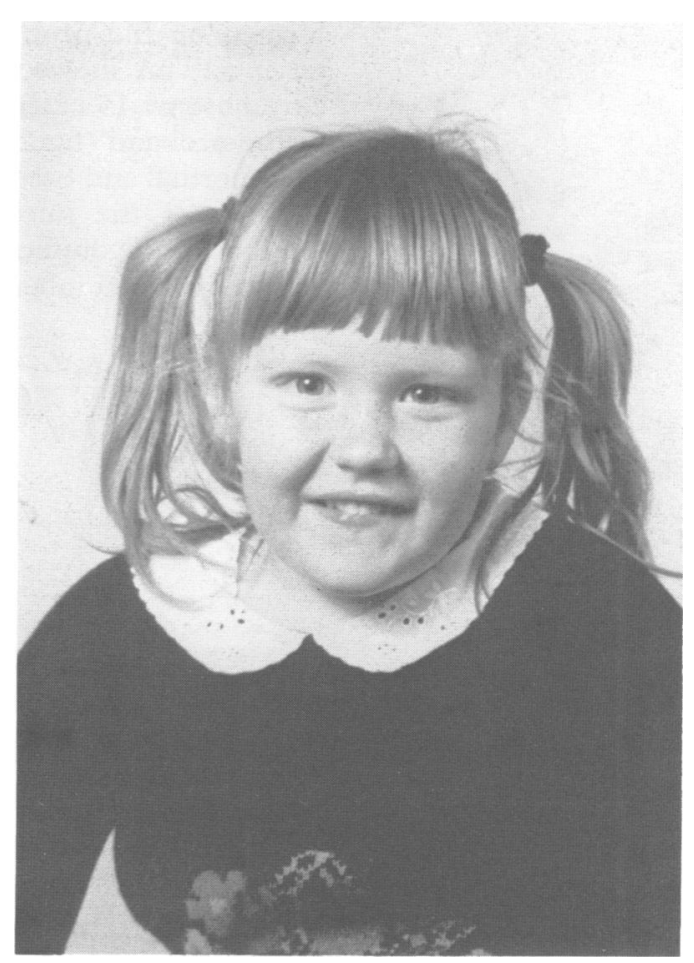

Figure 1 The proband aged $4 \frac{1}{2}$ years. 


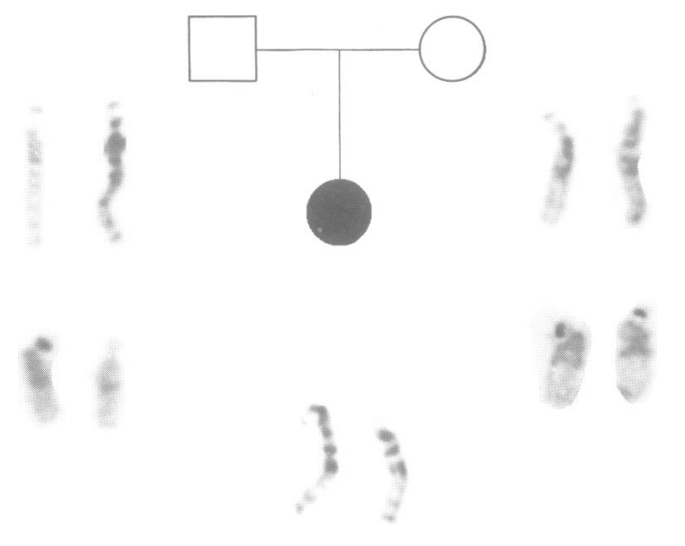

Figure 2 Partial karyotype showing chromosome 15 in the family. The proband has a large amount of extra material in proximal $15 q$. The 'inserted' chromosome is on the left and an extra band is shown both by GTG banding (upper) and in the Ag/NOR stained chromosome (lower). The normal chromosome 15 (right) does not stain with silver. The chromosomes 15 are uninformative as to short arms and satellites as they are similar in size and staining. Both parents have chromosomes 15 with similar sized short arms and all are satellited. None of them shows extra material in proximal 15q. However, both the maternal chromosomes 15 have Ag/NOR staining while only one of the paternal chromosomes has. Thus the normal, non-silver staining chromosome 15 in the affected daughter has been inherited from her father, and the 15 with extra material was therefore inherited from her mother.

She is now able to say some simple sentences and is a happy child with no behavioural problems.

\section{Cytogenetic studies}

High resolution cytogenetic analyses were performed on the proband and on both of her parents. This showed a de novo duplication of chromosome 15 extending from 15q11 to q13 in the proband (fig 2). Parental chromosomes were normal and based on the pattern of silver staining of the nucleolus organiser regions $(\mathrm{Ag} / \mathrm{NOR})$ the duplication is most likely on the chromosome 15 inherited from the mother.

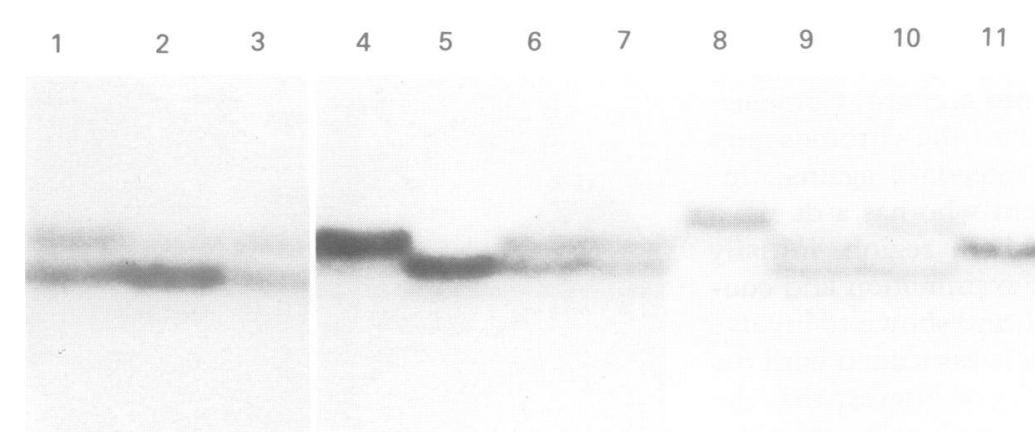

Figure 3 D15S10 (TD3.21) alleles: track 1 mother; track 2 proband; tracks 3, 6, 7, 9 controls heterozygous for the 181 and 179 bp alleles; tracks 4, 5, 11, homozygous controls; tracks 8 and 10, examples of the $183 \mathrm{bp}$ alleles. In track 2 the greatly increased intensity of the lower band can be observed. The heterozygous controls show similar intensities of the two bands.

\section{Molecular genetic studies} METHODS

The CA repeat at the D15S10 (pTD3-21) locus on chromosome $15^{8}$ was analysed in the proband, both parents, and controls using the polymerase chain reaction technique. The reported polymorphism consists of two amplified bands of 179 and 181 base pairs. We have also observed a third allele of $183 \mathrm{bp}$ at a frequency of $2 \%$ and a fourth allele of $161 \mathrm{bp}$ once in 256 chromosomes. DNA amplification was carried out in a $50 \mu \mathrm{l}$ volume containing 25 to $100 \mathrm{ng}$ of genomic DNA template extracted from peripheral blood lymphocytes. ${ }^{9}$ The reaction solution contained $25 \mathrm{pmol}$ of each oligodeoxynucleotide primer, $200 \mu \mathrm{mol} / 1$ dATP, TTP, and dGTP, $20 \mu \mathrm{mol} / 1 \mathrm{dCTP}$ (Pharmacia UK), $1 \mu \mathrm{Ci} \alpha^{32} \mathrm{P}-\mathrm{dCTP}(3000 \mathrm{Ci} /$ $\mathrm{mmol}), \quad 50 \mathrm{mmol} / 1 \mathrm{KCl}, \quad 10 \mathrm{mmol} / 1$ Tris (pH 8.8), $1.5 \mathrm{mmol} / 1 \mathrm{MgCl}_{2}, 0.1 \%$ Triton X100, and 0.5 to 1.0 units of Taq Polymerase (Promega). Samples were overlaid with mineral oil and after initial denaturations at $94^{\circ} \mathrm{C}$ for 10 minutes were processed through 30 temperature cycles at $94^{\circ} \mathrm{C}$ (30 seconds), $56^{\circ} \mathrm{C}\left(20\right.$ seconds), and $72^{\circ} \mathrm{C}$ ( 30 seconds) in a PHC-2 thermocycler (Techne). The reaction mix was diluted 5 to 10 fold and $2 \mu \mathrm{lmixed}$ with $2 \mu$ l sequencing stop solution. The PCR products were run on a $6 \%$ sequencing gel for two hours at $55 \mathrm{~W}$.

\section{RESULTS}

Fig 3 shows an autoradiograph of amplified DNA from the proband, her mother, and several controls. The father was homozygous lower and, therefore, uninformative. Although a slight shadow is seen below each band, probably from the GT strand, comparison of the proband's track with controls shows that no other subject shows this increased density of signal in a heterozygote, indicating increased copy number of sequences in the D15S10 region.

\section{Discussion}

The de novo duplication of 15q11-13 was detected by both cytogenetic and molecular genetic techniques, and as extensive tests have failed to show another cause for the proband's developmental delay, it seems reasonable to assume that this abnormality is the cause of her developmental problems and ataxia. Shohat et $a l^{10}$ described a case with an obesity syndrome who also had a de novo duplication of 15q1113 and reviewed 10 other patients. Rauch and Nevin $^{11}$ reported a further five patients. The clinical features of all 16 patients are documented in the table along with those of our patient. None was phenotypically similar to our patient. Rauch and Nevin ${ }^{11}$ also commented that they had seen similar cytogenetic abnormalities in two normal subjects. It is possible that in some of these patients the apparent extra material on chromosome 15 was in fact because of normal variation in the length of 15q11.2 without necessarily having any material duplicated. The clinical problems 
Previously reported cases of 15q11-13 duplication.

\begin{tabular}{|c|c|c|c|}
\hline Author & Age & Phenotype & Duplication \\
\hline $\begin{array}{l}\text { De France } \text { et } a l^{12} \\
\text { Fuhrmann-Rieger } \text { et } a l^{13}\end{array}$ & $\begin{array}{l}6 y \\
12 y\end{array}$ & $\begin{array}{l}\text { Typical PWS } \\
\text { Short stature, diabetes, large } \\
\text { incisors, ? Cohen }\end{array}$ & $\begin{array}{l}q 12-q 15 \\
q 11-q 13\end{array}$ \\
\hline $\begin{array}{l}\text { Stallard and Van Dyke } \\
\text { Stallard and Van Dyke }\end{array}$ & $\begin{array}{l}\text { Fetus } \\
\text { Stillborn }\end{array}$ & $\begin{array}{l}\text { Apparently normal } \\
\text { Anal atresia, renal and } \\
\text { skeletal abnormalities }\end{array}$ & $\begin{array}{l}\mathrm{q} 11.2-\mathrm{q} 13.3 \\
\mathrm{q} 11.2-\mathrm{q} 13\end{array}$ \\
\hline Pattigrew et al ${ }^{15}$ & $9 y$ & Typical PWS & ?q11.2-q13 \\
\hline Pattigrew et al ${ }^{15}$ & $13 y$ & $\begin{array}{l}\text { Cleft palate, mild mental } \\
\text { retardation }\end{array}$ & $\begin{array}{l}\mathrm{q} 11.2-\mathrm{q} 13 / \\
\mathrm{q} 12-\mathrm{q} 13\end{array}$ \\
\hline Brookwell and Veleba ${ }^{16}$ & $10 y$ & $\begin{array}{l}\text { Short stature, clinodactyly, } \\
\text { mild mental retardation }\end{array}$ & q11-q13 \\
\hline Brookwell and Veleba ${ }^{16}$ & $4 \mathrm{mth}$ & $\begin{array}{l}\text { Jejunal atresia, brain } \\
\text { malformations }\end{array}$ & $\mathrm{q} 11-\mathrm{q} 13$ \\
\hline $\begin{array}{l}\text { Brookwell and Veleba }{ }^{16} \\
\text { Barry et al }{ }^{17} \\
\text { Shohat et } a l^{10}\end{array}$ & $\begin{array}{l}34 \mathrm{y} \\
13 \mathrm{y} \\
26 \mathrm{y}\end{array}$ & $\begin{array}{l}\text { Normal phenotype } \\
\text { Typical PWS } \\
\text { Obesity, hypothyroidism, } \\
\text { acanthosis nigricans, mental } \\
\text { retardation }\end{array}$ & $\begin{array}{l}\mathrm{q} 11-\mathrm{q} 13 \\
\mathrm{q} 11.2-\mathrm{q} 13.3 \\
\mathrm{q} 11.2-\mathrm{q} 13\end{array}$ \\
\hline Rauch and Nevin ${ }^{11}$ & Neonate & $\begin{array}{l}\text { Encephalocele, cystic brain } \\
\text { lesion }\end{array}$ & $\mathrm{q} 11.2-\mathrm{q} 13$ \\
\hline $\begin{array}{l}\text { Rauch and Nevin }{ }^{11} \\
\text { Rauch and Nevin } \\
\text { Rauch and Nevin }\end{array}$ & $\begin{array}{l}? \\
? \\
?\end{array}$ & $\begin{array}{l}\text { Similar to PWS } \\
\text { Primary amenorrhoea } \\
\text { Insulin dependent diabetes, } \\
\text { epilepsy }\end{array}$ & $\begin{array}{l}\mathrm{q} 11.2-\mathrm{q} 13 \\
\mathrm{q} 11.2-\mathrm{q} 13 \\
\mathrm{q} 11.2-\mathrm{q} 13\end{array}$ \\
\hline $\begin{array}{l}\text { Rauch and Nevin }{ }^{11} \\
\text { Rauch and Nevin }\end{array}$ & $?$ & $\begin{array}{l}\text { Personality disorder } \\
\text { Normal phenotype, } \\
\text { infertility }\end{array}$ & $\mathrm{q} 11.2-\mathrm{q} 13$ \\
\hline $\begin{array}{l}\text { Clayton-Smith et al } \\
\text { (this paper) }\end{array}$ & $6 y$ & $\begin{array}{l}\text { Ataxia, mild mental } \\
\text { retardation, speech delay }\end{array}$ & $\mathrm{q} 11.2-\mathrm{q} 13$ \\
\hline
\end{tabular}

would therefore have another cause. Alternatively the extra material may not have been derived from chromosome 15 . This would be difficult to prove without molecular genetic studies. Most deletion cases of AS (and PWS) involve large deletions including DNA probes D15S9, D15S10, D15S11, D15S12, and D15S13. ${ }^{18}$ However, a report of three cases within one family found a much smaller deletion involving $D 15 S 10^{19}$ inherited through the grandfather to the mother without phenotypic effect, and passed on by the mother to three affected children. D15S10 may, therefore, be regarded as close to a 'critical' region in AS. In this case we have shown that D15S10 is duplicated.

It is now well established that Prader-Willi syndrome can result from a deletion of the paternally derived chromosome 15 whereas in Angelman syndrome the deletion is maternally derived..$^{20} \mathrm{~A}$ reasonable hypothesis, therefore, is that the parental origin of a chromosome 15q11-q13 duplication influences the resulting phenotype. Berry et $a l^{17}$ reported a patient with classical PWS who inherited a 15q duplication from his normal father. Given that our patient has some clinical features in common with Angelman syndrome we might therefore expect that the duplication would be of the other parental origin, that is, maternal. The cytogenetic studies suggest this is the case. Molecular studies do not so far provide any information on the parental origin of the proband's duplication but prove that the extra material is derived from 15q. A lymphoblastoid cell line is available from the proband.

JC-S is an Action Research Training Fellow and XJC is funded by a fellowship from the World Health Organization.

1 Butler MG. Prader-Willi syndrome: further cytogenetic confusion. Clin Genet 1990;26:379-82.

2 Ledbetter DH, Mascarello JT, Riccardi VM, et al. Chromosome 15 abnormalities and the Prader-Willi syndrome: a follow-up repor

3 Kaplan LC, Wharton R, Elias E, et al. Clinical heterogeneity associated with deletions in the long arm of chromosome 15. Report of three new cases and their possible genetic significance. Am $\mathcal{f}$ Med Genet 1987;28:45-53.

4 Magenis RE, Brown MG, Lacy DA, et al. Is Angelman syndrome an alternate result of $\operatorname{del}(15)(\mathrm{q} 11-\mathrm{q} 13)$ ? $A m \mathcal{F}$ Med Genet 1987;28:829-38.

5 Pembrey M, Fennell SJ, Van den Berghe J, et al. The association of Angelman's syndrome with deletions within 15q11-13. F Med Genet 1989;26:73-7.

6 Hultén M, Armstrong S, Challinor P. Genomic printing in an Angelman and Prader-Willi translocation family. Lancet 1991;338:638-9.

7 Angelman H. "Puppet children": a report on three cases. Dev Med Child Neurol 1965;7:681-99.

8 Lindeman R, Kouts S, Woodage T, et al. Dinucleotide repeat polymorphism near D15S10 in the Prader-Willi repeat polymorphism near D15S10 in the Prader-Willi
chromosome region (PWCR). Nucleic Acids Res chromosome

9 Jeanpierre $M$. A rapid method for the purification of DNA from blood. Nucleic Acids Res 1987;15:9611.

10 Shohat M, Shohat T, Rimoin DL, et al. Rearrangement of chromosome 15 in the region q11.2-q12 in an individual with obesity syndrome and her normal mother. $\mathrm{Am} \mathcal{F} \mathrm{Med}$ Genet 1990;37:173-7.

11 Rauch LA, Nevin NC. Duplication of 15q11.2-15q13 in five cases with different phenotypes. $\mathcal{f}$ Med Genet 1991;28:573-4.

12 De France HF, Beemer FA, Ippel PF. Duplication in chromosome $15 q$ in a boy with the Prader-Willi syndrome: further cytogenetic confusion. Clin Genet 1984;26:379-82.

13 Fuhrmann-Rieger A, Kohler A, Fuhrmann W. Duplication of insertion in Prader-Willi or Cohen syndrome? Clin Genet 1984;25:347-52.

14 Stallard R, Van Dyke D. Familial duplications of proximal $15 \mathrm{q}$ in normal individuals. Am $\mathcal{f}$ Hum Genet 1986;39:A133.

15 Pattigrew AL, Gollin M, Greenberg F, et al. Duplication of proximal $15 \mathrm{q}$ as a cause of the Prader-Willi syndrome. Am $\mathcal{F}$ Med Genet 1987;29:791-802.

16 Brookwell R, Veleba A. Proximal 15q variant with normal phenotype in three unrelated individuals. Clin Genet 1987;31:311-14.

17 Berry R, McGavran L, Robinson J, et al. Familial duplication of proximal $15 \mathrm{q}$ in a Prader-Willi individual and her normal father. Am f Hum Genet 1987;41:A114.

$18 \mathrm{Knoll} \mathrm{JHM}$, Nicholls RD, Magenis RE, et al. Angelman syndrome: 3 molecular classes identified with chromosome $15 \mathrm{q} 11 \mathrm{q} 13$ specific DNA markers. Am $\mathcal{F}$ Hum Genet 1990;47:149-55.

19 Hamabe J, Kuroki Y, Imaizumi K, et al. DNA deletion and its parental origin in Angelman syndrome patients. $A m \mathcal{F}$ Med Genet 1991;41:64-88.

20 Knoll JHM, Nicholls RD, Magenis RE, et al. Angelman and Prader-Willi syndrome share a common chromosome 15 deletion but differ in parental origin of the deletion. Am $\mathcal{F}$ Med Genet 1989;32:285-90. 